УДК 621.593

'В.Л. Бондаренко, доктор техн. наук; ${ }^{2}$ А.Н. Кислый; ${ }^{3}$ О.В. Дьяченко, канд. техн. наук

${ }^{1}$ Московский государственный технический университет им. Н.Э. Баумана, Лефортовская наб., д. 1, факультет «Энергомашиностроение», г. Москва, РФ, 105005

${ }^{2,3} \mathrm{OOO}$ «Криоин Инжиниринг», Таможенная пл., 1А, г. Одесса, Украина, 65026

e-mail: ${ }^{2} v b o n d a r e n k o @$ raregases.org; ${ }^{2} a l e k s a n d r . a n k .32 @ g m a i l . c o m ;{ }^{3}$ diachenko-ov@yandex.ru

ORCID: 'http://orcid.org/0000-0003-1562-7255; ${ }^{2 h t t p: / / o r c i d . o r g / 0000-0001-5422-9511 ; ~}$

${ }^{3}$ http://orcid.org/0000-0001-5999-3965

\title{
КРИПТОН И КСЕНОН ВЫСОКОЙ ЧИСТОТЫ. МЕТОАЫ ОЧИСТКИ ОТ МИКРОПРИМЕСЕЙ
}

\begin{abstract}
Атмосферный воздух является основным источником редких газов. В процессе получения инертных газов высокой чистоты вместе с Kr и Хе происходит обогащение близких к ним по свойствам компонентов воздуха. Нсследованы пути попадания в атмосферу микропримесей химического происхождения, проанализированы свойства бинарных смесей, образуемых компонентами воздуха. Нсследованы способы очистки целевых продуктов от указанных веществ, приведены имеющиеся в литературе технические данные предназначенных для этого опытно-промышленных установок. Предоставленная информация будет полезна специалистам, занимающимся проектированием и эксплуатацией аппаратов, входящих в технологическую структуру получения тяжелых инертных газов.
\end{abstract}

Ключевые слова: Криптон и ксенон высокой чистоты. Очистка от фторсодержащих компонентов воздуха. Выжигание. Катализатор. Ректификация. Адсорбция.

\section{BBEAEHИЕ}

Основным источником промышленного получения тяжелых инертных газов является атмосфера Земли. Криптон- и ксенон-содержащие смеси извлекают в качестве побочных продуктов в процессе разделения воздуха [1-7].

В последние несколько десятилетий состав атмосферного воздуха претерпевает существенные изменения, обусловленные деятельностью человека [8-15]. Наиболее масштабным и значительным является загрязнение среды несвойственными ей веществами химической природы промышленно-бытового происхождения. Среди них - газообразные и аэрозольные вещества, в состав которых входят различные фторсодержащие газы: $\mathrm{CF}_{4}, \mathrm{C}_{2} \mathrm{~F}_{6}, \mathrm{SF}_{6}$ и другие соединения. Указанные газы концентрируются во всех технологических процессах, направленных на извлечение и обогащение $\mathrm{Kr}$-Хе-концентратов и получение чистых газовых продуктов [16-25].

Представленная работа посвящена анализу источников загрязнения атмосферы фторсодержащими газами, свойств смесей, образованных указанными веществами с тяжелыми инертными газами. Целью исследования является поиск экономичных методов обогащения и очистки криптона и ксенона от микропримесей, определение этапа технологии, где их внедрение будет наиболее рациональным.

\section{2. ИСТОЧНИКИ И ОСНОВНЫЕ ТИПЫ МИКРОПРИМЕСЕЙ В КРИПТОН- И КСЕНОН-СОАЕРЖАЩИХ СМЕСЯХ}

2.1. Атмосфера Земли - источник микропримесей, вызывающих сложности в процессе получения продукции высокого качества

Современные жители Земли, несмотря на все достижения цивилизации, остаются тесно связанными с окружающим миром. С развитием промышленности вмешательство человека в природу привело к значительным изменениям биосферы нашей планеты, в том числе состава воздуха, которым мы дышим. Атмосфера Земли подвергается нарастающему антропогенному воздействию, приводящему к появлению и накоплению различных химических веществ [8-11].

В настоящее время в воздухе промышленных городов в ощутимых количествах присутствует целый «букет» вредных соединений, образующихся в виде побочных продуктов как результат реализации разнообразных технологических процессов. Повышение содержания отдельных газов приводит к возникновению, так называемого, парникового эффекта - увеличения средней температуры воздуха в связи с недостаточной прозрачностью атмосферы для инфракрасных лучей. Этот эффект не позволяет части тепловой энергии, излучаемой Солнцем и отражаемой от поверхности Земли, беспрепятственно покидать пределы земного притяжения. Основные газообразные компоненты, ответственные за парниковый эффект, - это водяной пар, диоксид углерода, озон, метан, окислы азота, хлори фторсодержащие соединения. Хлорфторуглероды, широко применяемые в различных отраслях народного хозяйства, при попадании в стратосферу вызывают разрушение озонового слоя планеты. Суммарный выброс газов, загрязняющих атмосферу, ещё

(с) В.Л. Бондаренко, А.Н. Кисльй, О.В. Дьяченко

DOI: http://dx.doi.org/10.18198/j.ind.gases.2016.0817 